\title{
KOMUNIKASI ANTARBUDAYA PENGUNGSI ETNIS ROHINGYA DENGAN MASYARAKAT ACEH DI CAMP BAYEUN ACEH TIMUR
}

\author{
Safrizal \\ Penyuluh Agama Pada Kantor Kementerian Agama Kabupaten Aceh Tamiang
}

\begin{abstract}
Abstrak
Penelitian ini berjudul komunikasi antarbudaya etnis Rohingya dengan masyarakat Aceh di Camp Bayeun Aceh Timur. Penelitian ini akan membahas Proses Komunikasi Antarbudaya antara Etnis Rohingya dengan Masyarakat Aceh di Camp Bayeun Aceh Timur dan hambatan yang mempengaruhi terjadinya komunikasi antarbudaya antar etnis pengungsi Rohingya dengan masyarakat Aceh di Camp Bayeun Aceh Timur serta dampak dari interaksi budaya antar etnis Rohingya dengan masyarakat Aceh. Penelitian ini ditempuh bertujuan untuk mengetahui tentang komunikasi antarbudaya antar etnis pengungsi Rohingya dengan masyarakat Aceh dalam kehidupan sosial di Camp Bayeun Aceh Timur dan hambatan-ambatan yang mempengaruhi proses komunikasi antarabudaya yang terjalin antara kedua belah pihak. Penelitian ini termasuk jenis penelitian lapangan dengan menggunakan pendekatan kualitatif dengan teknik pengumpulan data berupa wawancara, observasi dan studi dokumentasi. Hasil penelitian diperoleh bahwa melalui komunikasi antarbudaya yang terjalin antara etnis Rohingya dengan masyarakat Aceh di Camp Bayeun Aceh Timur secara sosial memberikan kemampuan bagi etnis Rohingya untuk bisa berkomunikasi dengan bahasa Indonesia. Hambatan-hambatan yang mempengaruhi proses komunikasi antarbudaya pengungsi etnis Rohingya dengan masyarakat Aceh di Camp Bayeun Aceh timur ialah meliputi hanya bisa secara lisan dan tidak bisa tulisan, perbedaan Gaya Hidup Antar Etnis Rohingya dan masyarakat Aceh, Penarikan diri dari komunikasi (kepribadian yang terlalu menutup diri dari lingkungan), Etnis Rohingya malas untuk berbicara.
\end{abstract}

Kata Kunci : Komunikasi antarbudaya, etnis Rohingya, masyarakat Aceh

\section{A. Pendahuluan}

Komunikasi antarbudaya adalah suatu bentuk komunikasi dimana sumber pesan dan penerimanya berasal dari budaya yang berbeda: perbedaan karakteristik perilaku, nilai/norma budaya dan lain-lain. Karakteristik tersebut bisa mengidentifikasi suatu bentuk interaksi komunikasi yang unik, yang harus memperhitungkan peranan dan fungsi budaya dalam proses komunikasi ( Saefullah, 2007 : 207).

Komunikasi antarbudaya sudah sering kali terjadi di indonesia, ada hal yang menarik yang terjadi di Aceh khusunya di Bayeun Kabupaten Aceh Timur, etnis Rohingya dari negara Myanmar yang merupakan minoritas Muslim di Arakan, mereka melarikan diri dari negara Myanmar yang mayoritasnya beragama Budha disebabkan oleh konflik. Sehingga etnis Rohingya terombang ambing dilaut hingga berbulan-bulan disebabkan kapal yang mereka 
gunakan rusak, dan kemudian ditolong oleh nelayan Aceh dan dibawa ke daratan pada tahun 2015.

Kehidupan etnis Rohingya di Aceh menjadi pusat perhatian pada saat itu, lantaran berbeda budaya dengan budaya yang ada di Aceh, baik dari aspek bahasa, praktik agama, sistem ekonomi, kebiasaan hidup dan lain-lain. Pada awal saat tiba di Aceh bahasa menjadi pusat permasalahan dikalangan etnis Rohingya karena menjadi penghambat dalam berinteraksi dengan masyarakat Aceh. Agar tidak terjadinya hambatan dalam interaksi dengan masyarakat Aceh dan tidak menjadi penghambat dalam kehidupan sehari-hari maka etnis Rohingya dalam kesehariannya belajar berkomunikasi menggunakan bahasa Indonesia dengan masyarakat aceh yang memasuki camp pengungsian. Ada juga pengungsi Rohingya lebih memilih belajar dan mendalami bahasa Aceh sebagaimana bahasa tersebut adalah bahasa pribumi yang lebih sering digunakan masyarakat Aceh setempat.

Ketika tiba di Aceh, etnis Rohingya diajarakan bahasa Inggris oleh relawan di camp pengungsian. karena bahasa Inggris merupakan salah satu bahasa Internasioanal agar ketika ada negara penerima suaka, mereka dapat berinteraksi dengan baik. Selama pengungsi Rohingya berada di Aceh, mereka banyak menerima bantuan dari organisasi Internasional salah satunya IOM dan UNHCR. IOM sebagai Organisasi Internasional dalam menjalankan tugasnya dibantu oleh relawan-relawan Indonesia khususnya Aceh seperti ACT (Aksi Cepat Tanggap), Tagana (Taruna Siaga Bencana), Dinas Sosial dan sebagainya. masyarakat Aceh hanya menyediakan lahan dan bantuan seadanya. Oleh sebab itu, bahasa Inggris juga mereka butuhkan untuk lebih memudahkan dalam berinteraksi dengan anggota IOM. Bahasa Indonesia dan bahasa Aceh mereka pelajari sendiri secara otodidak dengan memperhatikan, menanyakan dan memahami ketika para relawan sedang berbicara.

Etnis Rohingya beradaptasi dengan masyarakat Aceh salah satunya dengan mengikuti bahasa yang digunakan oleh masyarakat pada umumnya. Hasil observasi awal, peneliti melihat adanya komunikasi antarbudaya yang terjadi di Camp pengungsian etnis Rohingya dalam melangsungkan kehidupan selama menetap tinggal di Aceh. Salah satu penemuan peneliti di lapangan, yaitu para pengungsi etnis Rohingya sudah mampu menggunakan bahasa Indonesia dalam berkomunikasi dengan relawan, masyarakat setempat yang datang ke Camp pengungsian. Selain itu komunikasi antarbudaya juga terjadi dalam sistem praktik keagamaan dan ekonomi, dimana masyarakat etnis Rohingya yang semula bermazhab Hanafi setelah tiba di Aceh harus terbiasa dengan masyarakat Aceh yang menggunakan mazhab Syafi'I sedangkan dalam hal sistem ekonomi masyarakat etnis diajarkan cara bercocok tanam jenis-jenis tanaman yang biasa tumbuh di Aceh seperti gambas, bayam, sawi, 
kangkung dan lain-lain. Berdasarkan hal ini maka dapat diketahui bahwa telah terjadi komunikasi antarbudaya etnis Rohingya dan masyarakat Aceh baik dari segi bahasa, sistem ekonomi maupun sistem praktik keagamaan.

Komunikasi antarbudaya menitikberatkan pada hubungan insani, yaitu suatu hubungan yang berlangsung antara orang yang berlainan budaya. Kedua orang atau kelompok etnis mewarnai budaya masing-masing etnis. Di dalam berkomunikasi di amati karakteristik komunikasi, budaya, bahasa, perilaku dan bahkan sistem kepercayaan melalui komunikasi antarpribadi. Pesan-pesan yang disampaikan untuk mencapai kesamaan makna sekaligus untuk menjaga keharmonisan guna saling menjaga keseimbangan antara sesama etnis ataupun dengan etnis yang berbeda (Usman, $2009: 43$ )

Budaya dan komunikasi mempunyai hubungan yang bersifat timbal balik. Keduanya saling mempengaruhi siapa yang berbicara/pemberi pesan, dengan siapa, tentang apa yang disampaikan pesan tersebut dan bagaimana orang yang menyampaikan pesan tersebut. Oleh sebab itu, perbedaan budaya sangat berpengaruh terhadap proses komunikasi.Sehingga peneliti tertarik untuk meneliti bagaimana proses komunikasi yang terjalin antar etnis Rohingya dengan masyarakat Aceh saat tinggal dan menetap di Camp Bayeun Aceh Timur.

\section{B. Pengertian Komunikasi}

Benard Berelson dan Gary A. Steiner menjelaskan bahwa komunikasi adalah transmisi informasi, gagasan, emosi, keterampilan dan sebagainya dengan menggunakan simbol-simbol, kata-kata, gambar, fitur, grafik dan sebagainya ( Mulyana, $2001: 62$ )

Carl I. Hovland mendefenisikan ilmu komunikasi sebagai upaya yang sistematis untuk merumuskan secara tegar asas-asas penyampaian informasi serta pembentukan pendapat dan sikap. Hovland mengatakan bahwa komunikasi adalah proses mengubah perilaku orang lain ( Efendy, 1992 : 10)

Walstrom, dari berbagai sumber menampilkan beberapa defenisi komunikasi, yakni :

a. Komunikasi antar manusia sering diartikan dengan pernyataan diri yang paling efektif

b. Komunikasi merupakan pertukaran pesan-pesan secara tertulis dan lisan melalui percakapan, atau bahkan melalui penggambaran yang imajiner.

c. Komunikasi merupakan pembagian informasi atau pemberian hiburan melalui kata-kata secara lisan atau tertulis dengan metode lainnya.

d. Komunikasi merupakan pengalihan informasi dari seorang kepada orang lain.

e. Komunikasi adalah Pertukaran makna antara individu dengan menggunakan sistem simbol yang sama

f. Komunikasi adalah proses pengalihan pesan yang dilakukan seorang melalui suatu saluran tertentu kepada orang lain dengan efek tertentu. 
g. Komunikasi adalah setiap proses pembagian informasi, gagasan atau perasaan yang tidak saja dilakukan secara lisan dantertulis melainkan melalui bahasa tubuh, atau gaya atau tampilan pribadi, atau hal lain di sekelilingnya yang memperjelas makna.( Liliweri, 2008 : 10)

Cara yang baik untuk menggambarkan komunikasi adalah dengan menjawab pertanyaan-pertanyaan berikut, Who Says What In Which Channel To Whom With What Effect? atau Siapa Mengatakan Apa Dengan Saluran Apa Kepada Siapa Dengan Pengaruh Bagaimana?

Berdasarkan defenisi Laswell dapat di turunkan unsur komunikasi yang saling bergantung satu sama lain, yaitu, Pertama, sumber (source) disebut dengan pengirim, penyandi, komunikator. Sumber adalah pihak yang berinisiatif untuk berkomunikasi. Kedua, pesan yaitu apa yang di komunikasikan oleh sumber kepada penerima. Ketiga, saluran/media yakni alat atau wahana yang digunakan sumber untuk menyampaikan pesannya kepada penerima. Keempat, penerima (receiver) sering disebut juga sasaran atau tujuan, komunikan, penyandi balik atau khalayak, pendengar yakni orang yang menerima pesan dari sumber. Kelima, efek yaitu apa yang terjadi pada penerima setelah ia menerima pesan tersebut ( Mulyana, 2009 : 68).

Dapat disimpulkan bahwa komunikasi itu proses penyampaian pesan antara komunikator dengan komunikan yang menimbulkaan feed Back atau umpan balik dengan menggunakan alat atau media sehingga menimbulkan efek pada komunikasi tersebut.

\section{Defenisi Budaya}

Budaya merupakan cerminan dan cara manusia hidup dalam masyarakat. Manusia belajar berpikir, merasa, mempercayai dan mengusahakan apa yang patut menurut budayanya. Bahasa, persahabatan, kebiasaan makan, praktik komunikasi, tindakan-tindakan sosial, kegiatan-kegiatan ekonomi dan politik, dan teknologi semua itu berdasarkan pola-pola budaya.

Kemudian pengertian ini berkembang dalam arti culture, yaitu sebagai segala daya dan aktivitas manusia untuk mengolah dan mengubah alam. berikut pengertian budaya atau kebudayaan dari beberapa ahli yang dikutip buku Ilmu Sosial dan Budaya Dasar oleh Elly M. Setiadi, dkk, yaitu:

1. B. Tylor, budaya adalah suatu keseluruhan kompleks yang meliputi pengetahuan, kepercayaan, kesenian, moral, keilmuan, hukum, adat istiadat dan kemampuan yang lain serta kebiasaan yang didapat oleh manusia sebagai anggota masyarakat. 
2. R. Linton, kebudayaan dapat dipandang sebagai konfigurasi tingkah laku yang dipelajari dan hasil tingkah laku yang dipelajari, dimana unsur pendukungnya di bentuk dan diteruskan oleh anggota masyarakat lainnya

3. Koentjaraningrat, mengartikan bahwa kebudayaan adalah keseluruhan sistem gagasan, milik diri manusia dengan belajar.

4. Selo Soemardjan dan Soelaeman Soemardi, mengatakan bahwa kebudayaan adalah semua hasil karya, rasa dan cipta masyarakat.

5. Herkovits, kebudayaan adalah bagian dari lingkungan hidup yang diciptakan oleh manusia.( Rakhmat, 2009 : 20 )

Budaya adalah suatu konsep yang membangkitkan minat. Secara formal budaya didefinisikan sebagai tatanan pengetahuan, pengalaman, kepercayaan, nilai, sikap, makna, hirarki, agama, waktu, peranan, hubungan ruang, konsep alam semesta, objek-objek materi dan milik yang diperoleh sekelompok besar orang dari generasi ke generasi melalui usaha individu dan kelompok.

Ada beberapa pemahaman kebudayaan di sampaikan oleh beberapa ahli dalam buku Ilmu Budaya Dasar oleh Rohiman Notowidagdo seperti:

A. L. Kloeber dan Clyde Kluckhon berpendapat bahwa kebudayaan adalah keseluruhan hasil perbuatan manusia yang bersumber dari kemauan, pemikiran dan perasaannya. Menurut Koentjaraningrat, kebudayaan adalah keseluruhan manusia dari kelakuan dan hasil kelakuan yang teratur oleh tata kelakuan yang harus di dapatnya dengan belajar dan yang semuanya tersusun dalam kehidupan masyarakat.(Notowidgdo, 1996 : 23)

Triandis menjelaskan bahwa kebudayaan merupakan elemen subjektif dan objektif yang dibuat manusia yang di masa lalu meningkatkan kemungkinan untuk bertahan hidup dan berakibat dalam kepuasan pelaku dalam ceruk ekologis, dan demikian tersebar di antara mereka yang dapat berkomunikasi satu sama lainnya, karena mereka mempunyai kesamaan bahasa dan mereka hidup dalam waktu dan tempat yang sama.( R. McDaniel, $2010: 27$ )

C. Klukhohn dan W. H. Kelly merumuskan kebudayaan sebagai hasil tanya jawab dengan para ahli antropologi, sejarah, hukum, psychologi yang implisit, explisit, rasional, irasional terdapat pada setiap waktu sebagai pedoman yang potensial bagi tingkah laku manusia.

J. P. H. Dryvendak mengatakan bahwa kebudayaan adalah kumpulan dari cetusan jiwa manusia sebagai yang beraneka ragam berlaku dalam suatu masyarakat tertentu. Mangunsarkoro, kebudayaan adalah segala yang bersifat hasil kerja jiwa manusia dalam 
arti yang seluas-luasnya. Sidi Gazalba, kebudayaan adalah cara berpikir dan merasa yang menyatakan diri dalam seluruh segi kehidupan dari segolongan manusia yang membentuk kesatuan sosial dengan suatu ruang dan suatu waktu.

Kebudayaan merupakan elemen subjektif dan objektif yang dibuat manusia yang di masa lalu meningkatkan kemungkinan untuk bertahan hidup dan berakibat dalam kepuasan pelaku dalam ceruk ekologis, dan demikian tersebar di antara mereka yang dapat berkomunikasi satu sama lainnya, karena mereka mempunyai kesamaan bahasa dan mereka hidup dalam waktu dan tempat yang sama.

Rasa meliputi jiwa manusia, mewujudkan segala kaidah-kaidah dan nilai-nilai sosial yang perlu untuk mengatur masalah-masalah kemasyarakatan dalam arti yang luas. Agama, ideologi, kebatinan dan kesenian yang merupakan hasil ekspresi jiwa manusia yang hidup sebagai anggota masyarakat termasuk di dalamnya.

Cipta merupakan kemampuan mental, kemampuan berpikir orang-orang yang hidup bermasyarakat yang antara lain menghasilkan filsafat serta ilmu pengetahuan. Cipta bisa berbentuk teori murni dan bisa juga telah disusun sehingga dapat langsung diamalkan oleh masyarakat. Semua karya, rasa dan cipta dikuasai oleh karsa orang-orang yang menentukan kegunaannya agar sesuai dengan kepentingan sebagian besar atau seluruh masyarakat.

Kebudayaan dilahirkan untuk mengembangkan kreatifitas manusia. Dengan kata lain, kebudayaan diciptakan untuk kelangsungan dan kemaslahatan manusia guna memenuhi kebutuhan hidup ( Soekanto, $20017: 62$ ).

\section{Pengertian Komunikasi Antarbudaya}

Komunikasi antarbudaya adalah suatu bentuk komunikasi dimana sumber pesan dan penerimanya berasal dari budaya yang berbeda: perbedaan karakteristik perilaku, nilai/norma budaya dan lain-lain. Karakteristik tersebut bisa mengidentifikasi suatu bentuk interaksi komunikasi yang unik, yang harus memperhitungkan peranan dan fungsi budaya dalam proses komunikasi.

Ada beberapa defenisi tentang kebudayaan berdasarkan pendapat para ahli dalam buku Ilmu Komunikasi Antarbudaya oleh Ilya Sunarwinadi antara lain:

1. Sitaram: Seni untuk memahami dan saling pengertian antara khalayak yang berbeda kebudayaan.

2. Samovar dan Porter: Komunikasi antarbudaya terjadi manakala bagian yang terlibat dalam kegiatan komunikasi tersebut membawa serta latar belakang budaya yang 
berbeda yang mencerminkan nilai yang dianut oleh kelompoknya berupa pengalaman, pengetahuan dan nilai.

3. Rich: Komunikasi antar budaya terjadi ketika orang-orang berbeda kebudayaan.

4. Stewart: Komunikasi antar budaya terjadi dibawah suatu kondisi kebudayaan yang berbeda bahasa, norma-norma, adat istiadat dan kebiasaan.

5. Sitaram dan Cogdell: Komunikasi antar budaya interaksi antara para anggota kebudayaan yang berbeda.

6. Carley H. Dood: Komunikasi antar budaya adalah pengiriman dan penerimaan pesanpesan dalam konteks perbedaan kebudayaan yang menghasilkan efek-efek yang berbeda.

7. Young Yun Kim: Komunikasi antar budaya adalah suatu peristiwa yang merujuk dimana orang-orang yang terlibat didalamnya baik secara langsung maupun tidak langsung memiliki latar belakang budaya.( Sunarwinardi, $1993: 7$ )

Hubungan antara budaya dan komunikasi bersifat timbal balik. Keduanya saling mempengaruhi siapa bicara dengan siapa, tentang apa dan bagaimana orang menjadi penyandi pesan, makna yang ia miliki untuk pesan dan kondisi-kondisinya untuk mengirim, memperhatikan dan menafsirkan pesan

\section{E. Peranan Bahasa Dalam Komunikasi Antarbudaya}

a. Bahasa

Bahasa memegang peran yang demikian besar dalam pengalaman manusia. Bahasa lebih dari sekedar alat mengkomunikasikan realitas. Bahasa merupakan alat untuk menyusun realitas. Bahasa yang berbeda akan menciptakan dan mengekspresikan realitas yang berbeda. Bahasa yang berbeda akan mengkategorikan pengalaman dengan cara yang berbeda. Bahasa yang berbeda memberi pola-pola alternatif untuk berfikir dan memahami.

Bahasa adalah sebagai alat komunikasi lingual manusia, baik secara lisan maupun tertulis. Ini adalah fungsi dasar bahasa yang tidak dihubungkan dengan status dan nilai-nilai sosial. Setelah dihubungka dengan kehidupan sehari-hari yang didalam nya selalu ada nilai dan status, bahasa itu tidak dapat ditinggalkan ia selalu mengikuti kehidupan manusia seharihari baik sebagai manusia anggota suku maupun anggota bangsa. ( Muslich, 2010:3 )

Kemampuan berbahasa sangat penting bagi perkembangan suatu bangsa, karna tanpa bahasa suatu pesan atau informasi yang akan disampaikan tidak bisa dipahami oleh si pendengar. Dengan kata lain bahasa memiliki fungsi yang terkait dengan identitas manusia 
sebagai makhluk sosial yang berbudaya, sejak lama maunusia telah menyadari pentingnya bahasa dan penguasaan bahasa untuk perkembangan peradaban hingga sekarang, semangkin maju peradaban manusia semangkin besar pula peran bahasa dalam kehidupan.

Banyak ahli yang telah mendefinisikan pengertian bahasa dalam buku Mengenal Kajian Wacan Bahasa Indonesia oleh Bida Palupi, diantaranya sebagai berikut:

1. Keraf dalam Smarapradhipa, memberikan dua pengertian bahasa. Pengertian pertama, menyatakan bahasa sebagai alat komunikasi antar anggota masyarakat berupa simbol bunyi yang dihasilkan oleh alat ucap manusia. Kedua, bahasa adalah sistem komunikasi yang mempergunakan simbol-simbol fokal (bunyi ujaran) yang bersifat arbitrer.

2. Owen dalam Stiawan, menjelaskan bahasa dapat didefinisikan sebagai kode yang diterima secara sosial atau sistem konvensional untuk menyampaikan konsep melalui kegunaan simbol-simbol yang dikehendaki dan komninasi simbol-simbol yang diatur oleh ketentuan.

3. Henri Guntur Tarigan, mendifinisikan bahasa menjadi dua. Pertama, bahasa adalah suatu sistem yang sistematik, barang kali juga untuk sistem generatif. Kedua, bahasa adalah seperangkat lambang-lambang mana suka atau simbol arbitrer.

4. Kusumo Budi Santoso, bahasa adalah rangkayan bunyi yang dihasilkan oleh alat ucap manusia secara sadar.

5. W.F Mackey, bahasa adalah suatu bentuk dan bukan suatu keadaan atau suatu sistem lambang bunyi yang arbitrer, atau juga suatu sistem dari sekian banyak sistemsistem, suatu sistem dari sekian banyak sistem-sistem.

6. Wahyu Wibowo, bahasa adalah sistem simbol bunyi yang bermakna dan berartikulasi (dihasilkan oleh alat ucap) yang bersifat arbitrer dan konvensional, yang dipakai sebagai alat berkomunikasi oleh sekelompok manusia untuk melahirkan perasaan dan pikiran.

7. A.R. Syamsudin, memberikan dua pengertian bahasa. Pertama, bahasa adalah alat yang dipakai untuk membentuk pikiran dan perasaan, keinginan dan perbuatan, alat yang dipakai untuk mempengaruhi dan dipengaruhi. Kedua, bahasa adalah tanda yang jelas dari kepribadian yang baik maupun yang buruk, tanda yang jelas dari keluarga dan bangsa, tanda yang jelas dari budi kemanusiaan.( Palupi, $2011: 2$ )

Berdasarkan definisi bahasa diatas dapat disimpulkan bahwa pada hakekatnya ada 7 hal yang mendasri bahasa, yaitu bahasa itu sistematik, bahasa bersifat mana suka 
(arbitrer), bahasa adalah ucapan dan vokal, bahasa merupakan simbol, dan bahasa merupakan komunikasi.

b. Bahasa dan komunikasi

Bahasa dan komunikasi memang merupakan dua bagian yang saling melengkapi dan sulit untuk dipahami sebagai bagian yang terpisah satu sama yang lain. Komunikasi tidak akan berlangsung bila tidak ada simbol-simbol (bahasa) yang dipertukarkan. Begitu juga sebaliknya, bahasa tidak akan memiliki makna jika tidak dilihat dalam konteks sosial atau ketika ia dipertukarkan. Bahassa yang tidak terkatakan hanyalah berupa pikiran saja, tetapi pikiran ini pun berbentuk dari pengalaman. Sehingga apapun bentuknya, bahasa merupakan hasil dari interaksi manusia.

Para ahli sosiologi percaya bahwa, komunikasilah yang melahirkan masyarakat atau kesatuan-kesatuan sosial. Masyarakat terbentuk karena adanya tujuan bersama yang melahirkan hubungan fungsional komplementer. Hubungan ini terjadi dengan bantuan komunikasi dan juga bahasa. Pemahaman kaum sosiologi inilah yang melahirkan salah satu perspektif penting dalam mengkaji ilmu komunikasi. Perspektif yang dimaksut adalah perspektif interaksional yang memandang komunikasi sebagai jalan bagi individu-individu untuk mengembangkan dirinya. Didalam diri individu mencakup esensi kebudayaan, masayarakat dan buah pikiran, sehingga individu memiliki nilai yang sangat tinggi

Perspektif ini juga membahas bahasa atau lambang sebagai hal yang dipertukarkan ketika manusia saling berinteraksi. Adapun makna sebagai hal yang dimiliki bersama, menurut perspektif ini adalah ciptaan situasi sosial. Jadi makna diperoleh ketika ada kesepakatan antara pihak-pihak yang mempertukarkan lambang. Kaitan antara bahasa dan komunikasi dalam perspektif interaksional, telah malahirkan cabang ilmu baru yaitu sosiolinguistik. Ilmu ini mempelajari penggunaan bahasa dalam interaksi sosial, karena mereka percaya bahwa bahasa merupakan inti dari interasi sosial. Bagi sisiolinguistik, interaksi sosial adalah proses tiada akhir yang melibatkan komunikasi didalamnya, dan sebagian besar komunikasi antarmanusia terjadi dengan menggunakan bahasa.( Kuswanto, 2008, 43 )

Sosiolinguistik ini berbeda dengan ilmu linguistik tradisonal, ia lebih tertarik meneliti bahasa ketika bahasa dipergunakan dalam logat sehari-hari. Namun dalam perkembangannya, sosiolinguistik lebih banyak berbicara mengenai bahasa yang dipergunakan oleh kelas-kelas sosial tertentu dalam masyarakat, dan bagaimana struktur berbicara dapat mengubah atau menentukan kelas sosial penutur yang menggunakannya. Cara penggunaan bahasa tergantung 
kepada status sosial, dan hubungan antara orang-orang yang menggunakannya, inilah yang menarik perhatian para sosiolinguis.

Ketika manusia berkomunikasi tentunya akan mengeluarkan simbol yakni bahasa, begitu juga sebaliknya, bahasa akan tercurahkan apabila dikomunikasikan. Seperti halnya juga sosial dan interaksi keduanya saling berkaitan satu sama lain. Dari pembahasan ini, maka lahirlah ilmu tentang Sosiolinguistik yaitu, penggunaan bahasa dalam interaksi sosial, karena bahasa merupakan inti dari interasi sosial.

c. Bahasa, komunikasi dan kebudayaan

Setiap masyarakat akan memiliki sistem komunikasi sendiri-sendiri, maka dengan sendirinya demi kelangsungan hidupnya, setiap masyarakat dapat membentuk kebudayaannya. Bahasa menjadi inti dari komunikasi sekaligus sebagai pembuka realitas bagi manusia. Kemudian dengan komunikasi, manusia membentuk masyarakat dan kebudayaannya. Sehingga bahasa secara tidak langsung turut membentuk kebudayaan pada manusia. Kebudayaan mencangkup semua hal yang dimiliki bersama oleh suatu masyarakat. Suatu kebudayaan mengandung semua pola kebiasaan-kebiasaan suatu masyarakat, seperti dalam bidang ekonomi, religi, hukum, kesenian dan lain sebagainya.

Kebudayaan sangat berarti bagi manusia dalam kehidupan masyarakat, karena kebudayaan mengajarkan manusia untuk hidup saling mengenal satu sama lainnya, Serta mengajarkan manusia untuk hidup selaras dengan alam.

Para pakar antropologi budaya percaya bahwa bahasalah yang memegang peranan utama dalam perkembangan budaya manusi. Hal ini karena bahasa merupakan wahana utama untuk meneruskan adat istiadat dari generasi yang satu ke generasi yang lainnya. Kemampuan manusia dalam membangun tradisi budaya, menciptakan pemahaman tentang realita yang diungkapkan secara simbolik, dan mewariskannya kepada generasi penerusnya, sangat tergantung pada bahasa. Sehingga disimpulkan bahwa bahasa adalah inti dari hakikat kemanusiaan.

Unsur pertama dalam sebuah kebudayaan adalah bahasa. Karena bahasa akan menentukan bagaimana masyarakat penggunanya mengkategorikan pengalamannya. Bahasa juga akan mempermudah dalam berinteraksi serta dapat menentukan konsep dan makna yang dipahami oleh masyarakat, sehingga memberikan pengertian mengenai pandanga hidup yang dimiliki oleh masyarakat itu sendiri. Budaya yang timbul pada manusia dalam kehidupan masyarakat, itu terbentuk dari hubungan antara simbol-simbol atau bahasa. ( Sukidin, $2002: 81$ ) 
Kaiatan antara bahasa, komunikasi dan kebudayaan melahirkan hipotesis relativitas linguistik dari Edward Safir dan Benjamin Lee Whorf, yang berbunyi "Struktur bahasa atau kaidah berbicara suatu budaya akan menentukan perilaku dan pola pikir dalam budaya tersebut".Para ahli antropologi menempatkan bahasa dalam unsur pertama dari tujuh unsur kebudayaan universal. Ada tujuh unsur kebudayaan yang dimaksud sebagai berikut:

1. Bahasa

2. Sistem pengetahuan

3. Organisasi sosial

4. Sistem peralatan hidup

5. Sistem mata pencaharian hidup

6. Sistem religi dan

7. Kesenian ( Kuswanto, 2008, 45 )

Unsur-unsur kebudayaan inilah yang digunakan oleh ilmuan antropologi untuk mempelajari suatu kebudayaan, dan memisahkan antara satu kebudayaan dengan kebudayaan yang lainnya.

Latar belakang dari sistem linguistik (tata bahasa) dari setiap bahasa bukan hanya suatu alat reproduksi untuk menyampaikan gagasan, pembentuk dan pemandu bagi aktivitas mental dalam komunikasi. Hal ini sejalan dengan pemikiran komunikolog yang menyatakan bahwa bahasa adalah kultural, diperoleh melalui interaksi dan sosialisasi dengan orang lain dan mempengaruhi penggunanya dengan kuat, seperti halnya adat istiadat mempengaruhi masyarakat.

Bahasa dan komunikasi menjadi hal yang utama bagi budaya, sebab Bahasa dan komunikasi memberikan dampak yang sangat bagus bagi budaya, dengan adanya bahasa dan komunikasi, maka dapat meneruskan adat istiadat dari generasi yang satu ke generasi yang lainnya. Budaya yang suda melekat pada diri manusia dan dijalaninya, disebabkan dengan adanya simbol-simbol atau bahasa yang dikomunikasikan.

\section{F. Teori-Teori Sosial dalam Kehidupan Masyarakat}

\section{Konstruksi Sosial}

Teori konstruksi sosial (sosial construction) merupakan teori sosiologi kontemporer yang berpijak pada sosiologi pengetahuan. Dalam teori ini terkandung pemahaman bahwa kenyataan dibangun secara sosial, serta kenyataan dan pengetahuan merupakan dua istilah kunci untuk memahaminya. Kenyataan adalah suatu kualitas yang terdapat dalam fenomenafenomena yang diakui memiliki keberadaan (being)-nya sendiri sehingga tidak tergantung 
kepada kehendak manusia; sedangkan pengetahuan adalah kepastian bahwa fenomenfenomen itu nyata (real) dan memiliki karakteristik yang spesifik Dunia kehidupan seharihari merupakan suatu yang berasal dari pikiran dan tindakan manusia, dan dipelihara sebagai yang nyata dalam pikiran dan tindakan.(L Berger, $1990: 1$ )

Asumsi-asumsi yang mendasari konstruksi realitas secara sosial adalah:

a. Realitas tidak hadir dengan sendirinya, tetapi diketahui dan dipahami melalui pengalaman yang dipengaruhi oleh bahasa.

b. Realitas dipahami melalui bahasa yang tumbuh dari interaksi sosial pada saat dan tempat tertentu.

c. Bagaimana realitas dipahami bergantung pada konvensi-konvensi sosial yang ada.

d. Pemahaman terhadap realitas yang tersusun secara sosial membentuk banyak aspek penting dalam kehidupan, seperti aktivitas berfikir, dan berprilaku.

Asumsi-asumsi di atas, teori konstruksi realitas secara sosial ada hubungannya dengan bahasa, interaksi sosial dan kebudayaan. Dengan bahasa maka manusia bisa memahami realitas sosial di lingkungan. Sebab bahasa memberikan pengaruh yang sangat kuat dalam kehidupan sosial.

Dalam teori konstruksi sosial dikatakan, bahwa manusia yang hidup dalam konteks sosial tertentu melakukan proses interaksi secara simultan dengan lingkungannya. Masyarakat hidup dalam dimensi-dimensi dan realitas objektif yang dikonstruk melalui momen eksternalisasi dan objektivasi dan dimensi subjektif yang dibangun melalui momen internalisasi. Baik momen eksternalisasi, objektivasi maupun internasliasi tersebut akan selalu berproses secara dialektik dalam masyarakat. Dengan demikian, yang dimaksud dengan realitas sosial adalah hasil dari sebuah konstruksi sosial yang diciptakan oleh manusia itu sendiri.

Dalam penjelasan Deddy $\mathrm{Nu}$ Hidayat, bahwa ontologi paradigma konstruktivis memandang realitas sebagai konstruksi sosial yang diciptakan oleh individu. Namun demikian, kebenaran suatu realitas sosial bersifat nisbi, yang berlaku sesuai konteks spesifik yang dinilai relevan oleh pelaku sosial ( Hidayat, 1999 : 39) Melihat berbagai karakteristik dan substansi pemikiran dari teori konstruksi sosial nampak jelas, bahwa teori ini berparadigma konstruktivis. 


\section{Fenomenologi}

Fenomenologi sebenarnya sudah ada sejak Emmanuel Kant yang mencoba memikirkan dan memilah unsur mana yang berasal dari pengalaman dan unsur mana yang terdapat didalam akal. Teori fenomenologi buah karya sosiolog Jerman dan diperkenalkan oleh Edmund Husserl. Yang beranjak dari kebenaran fenomena, seperti yang tampak apa adanya. Suatu fenomena yang tampak sebenarnya merupakan refleksi realitas yang tidak berdiri sendiri, karena yang tampak itu adalah objek yang penuh dengan makna yang transendental. Oleh karena itu, untuk mendapatkan hakikat kebenaran, maka harus mampu berfikir lebih dalam lagi melampaui fenomena yang tampak itu, hingga mendapatkan "Meaningfulness".( Wirawan,2013:34)

Fenomenologi mengkaji tentang apa dan bagaimana pemahaman individu terhadap fenomena sosial, yang dibangun dari tipefikasi yang saling bertautan, menciptakan maknamakna tertentu sebagai pengetahuan umum yang diterima apa adanya, dan dipertukarkan dengan orang lain. Dalam Fenomenologi terdapat istilah "Lebenswelt”(“life-world'atau 'Dunia Kehidupan') yang terdiri dari dunia atau semesta yang rumit dan lengkap, termasuk lingkungan fisik, lingkungan sosial, interaksi antar manusia (intersubyektifitas) dan nilai-nilai yang dihayati. Lebenswelt merupakan realitas sosial sebagaimana dipahami dan dianut oleh orang-orang biasa (orang awam) dalam kehidupanya sehari-hari.

Berger mengungkapkan bahwa Tugas para sosiolog adalah untuk menemukan hakikat masyarakat dibalik gejala-gejala sosial dari pengalaman dan pemahaman orang-orang awam terhadap realitas sosialnya dalam kehidupan keseharian. Realitas tercipta dalam pengalaman dan pemahaman inter-subyektif antar individu secara terus menerus dalam sebuah interaksi sosial khususnya lewat media bahasa .

Trilogi realitas sosial. Realitas sosial tercipta dan terpelihara dalam relasi dialektis antar individu dan dunia disekitarnya. Upaya memahami realitas dilakukan dengan melihat proses interaksi dialektis antara diri (individu) dan dunia kenyataan sosio-kulturalnya yang berlangsung terus menerus tanpa akhir tersebut. Proses dialektika ini dapat dipahami dalam tiga momen simultan:

a. Eksternalisasi (proses penyesuaian diri dengan dunia sosio-kultural sebagai produk manusia). Eksternalisasi dipahami sebagai proses penciptaan realitas sosial oleh semua individu bersama-sama. Perlu dipahami, bahwa setiap individu yang terlibat mengalami proses sosialisasi yang berbeda-beda sehingga memiliki pemahaman tentang masyarakat yang berbeda pula. Interaksi antar individu dan juga dengan dunia sosio-kulturalnya ini dipandang sebagai proses penciptaan realitas sosial 
b. Obyektivasi (proses interaksi sosial dalam dunia intersubyketif yang dilembagakan atau mengalami institusionalisasi). Realitas sosial yang tercipta dalam Eksternalisasi secara berangsur-ansur terlembagakan dalam struktur sosial suatu masyarakat. Proses pelembagaan ini dapat pula sebagai upaya pelepasan diri realitas sosial dari individuindividu penciptanya. Realitas sosial yang terlembagakan tidak lagi dipengaruhi dan diintervensi oleh individu dalam masyarakat

c. Internalisasi (proses individu mengidentifikasikan diri dengan lembaga-lembaga sosial atau organisasi sosial dimana ia menjadi anggotanya). Proses selanjutnya, setelah realitas sosial terlembagakan dalam struktur sosial, individu-individu memahami dan menghayatinya sebagai obyek independent. Proses pemahaman ini yang disebut sebagai internalisasi oleh individu terhadap realitas sosial. Masingmasing individu mengalami internalisasi yang beragam sehingga eksternalisasi mereka pun beraneka macam pula

Peneliti menggunakan teori Fenomenologi agar memahami lebih jauh kehidupan sosial dilingkungan yang akan diteliti. Fenomenologi berupaya untuk mengungkapkan bagaimana aksi sosial dan situasi sosial. Manusia tidak terlepas dari komunikasi, dan begitu juga komunikasi tidak bisa dilakukan tanpa berinteraksi. Kekhususan manusia terletak pada intensional psikisnya yang ia sadari, yang dikaitkan dengan dunia arti dan makna. Jadi dunia makna manusia ini dapat diteliti dengan metode fenomenologi.

\section{Teori Etnometodelogi}

Komunikasi antarbudaya Dalam hal penelitian ini mencoba mengaplikasikan teori Etnometodologi, serta menggabungkan fenomenologi dengan sosiologi untuk menghasilkan pandangan yang unik. Etnometodologi memfokuskan pada tindakan dan interaksi. Sedangkan fenomenologi cendrung menekankan pada kesadaran dan budaya.

Etnometodologi dikembangkan oleh Harold Garfinkel, yang selama 20 tahun melaksanakan penelitian di Harvard di bawah arahan Talcott. Talcott Parsons memiliki pengaruh yang sangat besar dalam pertumbuhan dan perkembangan sosiologi di Amerika, bahkan dunia dalam beberapa dekade. Sebagian besar teorinya dihasilkan melalui penelitian empiris di University of California, Los Angeles. Oleh karena itu Harold Garfinkel dapat dikatakan sebagai tokoh hasil pendidikan sosiologi tradisi Amerika. Etnometodologi merupakan suatu studi empiris tentang bagaimana orang menanggapi pengalaman dunia sosialnya sehari-hari. Etnometodologi mempelajari tentang realitas sosial atas interaksi yang 
berlangsung sehari-hari. Garfinkel mengemukakan tiga hal kunci dasar etnometodologi, yaitu: (1) ada perbedaan antara ungkapan yang objektif dan yang diindikasikan; (2) refleksitas berbagai tindakan praktis; dan (3) kemampuan menganalisa tindakan tersebut dalam kehidupan sehari-hari. ( Wirawan,2013:153)

Etnometodologi mengisyaratkan upaya-upaya mendeskripsikan dan memahami masyarakat dalam kehidupan sehari harinya misalnya, bagaimana pola interksi, cara berfikir, perasaan mereka cara berbicara.

Bahasa tidak terlepas dari komunikasi, begitu juga komunikasi tidak bisa dilakukan tanpa ada interaksi. Perbedaan budaya bisa menjadi penghambat dalam komunikasi, seseorang ketika berkomunikasi haruslah mengetahui bagaimana bahasa yang digunakan dalam komunikatif suatu masyarakat, yaitu bagaimana menggunakan bahasa dalam masyarakat yang berbeda kebudayaan. Etnometodologi juga melihat bagaimana cara berfikir disuatu masyarakat yang berbeda kebudayaan dan juga gaya saat berbicara.

Menurut Bog dan Biklen pengertian etnometodologi tidaklah selalu mengacu pada suatu model atau metode pengumpulan data pada saat peneliti melakukan penelitian dilapangan, akan tetapi lebih merupakan arah kemana problematika penelitian itu tertuju. Dengan demikian, etnometodologi mengacu pada suatu studi mengenai bagaimana seorang individu dalam suatu komunitas bertindak dan bertingkah laku serta berusaha memahami kehidupan sehari-hari aktor yang diteliti.

Tetapi hal ini sejalan dengan Harold Garfinkel seorang peletak dasar etnometodologi. Yang bahwa etnometodologi bertujuan untuk bisa mendeskripsikan dan memahami masyarakat dalam sehari-hari. Misalkan bagaimna pola interaksi, cara berfikir, perasaan mereka dan juga cara bicara mereka. ( Bungin, 2008 : 157)

\section{G. Metode Penelitian}

\section{Jenis dan Pendekatan Penelitian}

Penelitian ini merupakan Penelitian lapangan (Field Research) dengan metode kualitatif. Pada umumnya alasan menggunakan metode kualitatif karena, permasalahan yang diteliti belum jelas, holistik, kompleks, dinamis dan penuh makna sehingga tidak mungkin data pada situasi sosial tersebut dijaring dengan metode penelitian kuantitatif dengan insrumen seperti test, kuesioner, pedoman wawancara.( Sugiyono, $2009: 292$ )

Teori yang digunakan adalah teori etnometodologi, yang merupakan studi empiris tentang bagaimana orang menanggapi pengalaman dunia sosialnya dalam sehari-hari. 
etnometodologi mempelajari tentang bagaimana realitas sosial atas interaksi yang berlangsung sehari-hari.

a. Sumber Data

Data adalah kesimpulan pengukuran terhadap variabel yang berisi informasi variabel. Dalam penelitian ini peneliti menggunakan dua sumber dan jenis data, yaitu:

- Data Primer

Data primer adalah data yang berupa field research (penelitian lapangan). yang berlokasi di Gampong Bayeun Kabupaten kabupaten Aceh Timur yakni di Camp Etnis Rohingya. Pengumpulan data dilakukan dengan mewawancarai narasumber yang terlibat langsung sebagai Pengungsi etnis Rohingya dan Masyarakat Aceh serta petugas yang berada di Camp.

- Data Sekunder

Data sekunder adalah sumber data yang tidak langsung memberikan data kepada pengumpul data. Sumber data sekunder (tambahan) berupa dokumen (seperti statistik dan foto). Data sekunder ini merupakan pendukung dalam perlengkapan data, baik berupa data dari dokumen, internet, buku-buku serta Jurnal Internasional yang berkaitan dengan masalah yang akan diteliti.

\section{Hasil Penelitian}

a. Proses Komunikasi Antarbudaya antara Etnis Rohingya dengan Masyarakat Aceh di Camp Bayeun Aceh Timur

Komunikasi adalah sebuah alat dalam berhubungan dengan orang lain untuk mencapai suatu informasi yang terjadi. Agar mengetahui bahasa yang berbeda dari kalangan suku lain maka dari itu penting adanya komunikasi dalam kehidupan kita sehari-hari. Sebelum etnis Rohingya bisa menggunakan bahasa Indonesia, terlebih dahulu mereka menggunakan bahasa non verbal atau bahasa isyarat dengan warga Aceh dalam berinteraksi.

Proses komunikasi yang terjadi disaat awal mula mereka terdampar di Aceh ialah dengan komunikasi non verbal atau dengan bahasa isyarat. Setelah satu tahun setengah berlalu etnis Rohingya yang berada didalam Camp Bayeun Aceh Timur sudah bisa menggunakan bahasa Indonesia dan juga satu orang dari mereka ada yang sudah fasih menggunakan bahasa Aceh. Bahasa tersebut pada umumnya digunakan oleh orang Aceh yang berada disekitaran Camp pengungsi Rohingya. 
Bahasa sangat dibutuhkan oleh manusia dalam berinteraksi Seperti halnya etnis Rohingya yang terdampar dipesisir laut Aceh, mereka kesulitan dalam berkomunikasi dengan masyarakat Aceh dikarenakan bahasa dan budaya yang berbeda sehingga saat berkomunikasi menggunakan bahasa isyarat sekalipun, sering terjadi kesalahpahaman makna dikarenakan budaya yang berbeda. Komunikasi nonverbal menjadi pegangan mereka ketika ingin pergi keluar Camp pengungsian saat membeli rokok atau jajanan lainnya. Merasa kurang efektif dengan bahasa isyarat, merekapun secara perlahan belajar bahasa Indonesia.

Pada awal mula etnis Rohingya yang berada di Aceh, mereka sama sekali tidak mengatahui bahasa yang digunakan oleh masayarakat Aceh, dan merekapun hanya diam dan jika memerlukan sesuatu mereka hanya menggunakan bahasa non verbal atau bahasa isyarat. Tetapi jika bahasa non verbal yang digunakan tidak dimengerti, maka etnis Rohingya berbicara melalui Board Members yakni: Internasional Concern Group For Rohingya (ICGR). Tetapi bukan itu saja, salah satu dari etnis Rohingya ada yang bisa menggunakan bahasa Inggris, dan komandan Satuan Polisi Pamung Praja (Satpol PP) penjaga Camp pengungsian juga bisa berbahasa Inggris, dengan demikian bahasa Indonesia dipahaminya melalui dengan bahasa Inggris.

b. Hasil Komunikasi antarbudaya pengungsi etnis rohingya dengan masyarakat Aceh dalam kehidupan sosial di Camp Bayeun Aceh Timur

Komunikasi antarbudaya adalah suatu bentuk komunikasi dimana sumber pesan dan penerimanya berasal dari budaya yang berbeda: perbedaan karakteristik perilaku, nilai/norma budaya dan lain-lain. Karakteristik tersebut bisa mengidentifikasi suatu bentuk interaksi komunikasi yang unik, yang harus memperhitungkan peranan dan fungsi budaya dalam proses komunikasi

Dalam kehidupan sosial yang terjadi di masyarakat maka tentu tidak bisa terlepas dari adanya budaya. Karena hubungan keduanya sangat berkaitan erat. Sebab kebudayaan adalah daya cipta dari masyarakat yang kemudian melebur dalam wujud-wujud kehidupan sosial sehari-hari masyarakat dalam berinteraksi satu dan lain. Dari paparan tersebut dapat dipahami bahwa secara sosial tindakan-tindakan masyarakat dapat mempengaruhi kebudayaan dan hal inilah yang akan peneliti kaji.

Dalam penelitian yang peniliti lakukan maka akan dipaparkan komunikasi antarbudaya yang terjalin diantara pengungsi etnis Rohingya dengan masyarakat Aceh di Camp Bayeun Aceh Timur dalam kehidupan sosial. Adapun hasil dari komunikasi antarbudaya diantara etnis Rohingya dengan masyarakat Aceh ialah seperti yang akan penulis paparkan berikut: 
- Mempermudah jalinan komunikasi antar keduanya

Dengan bisa berbahasa Indonesia, mereka dapat dengan mudah keluar dari Camp pengungsian untuk berbaur dengan masyarakat Aceh lainnya pergi jalan-jalan kekota Langsa ataupun belanja ke pasar dengan transportasi umum tanpa takut orang Aceh tidak mengerti dengan bahasa yang mereka gunakan seperti pada awal pertama mereka berada di Aceh

- Terciptanya budaya baru

Bahasa indonesia di pelajari etnis Rohingya secara otodidak, tanpa pembelajaran secara formal seperti orang indonesia pada umumnya di bangku sekolah. Sehingga bahasa indonesia yang mereka gunakanpun susunan katanya tidak teratur. Meskipun demikian, mereka lebih paham dengan kata-kata yang tidak beraturan susunannya seperti, mau makan, menjadi makan mau, sudah mandi menjadi mandi sudah. Dari pada bahasa indonesia dengan susunan kata yang sebenarnya. Sehingga masyarakat Aceh berkomunikasi dengan mereka juga menggunakan bahasa indonesia yang tidak beraturan susunan katanya agar mereka lebih mudah memahaminya.Bahasa Indonesia yang digunakan tidak teratur atau terbalik-balik dalam pengucapan Seperti contoh pada tabel dibawah:

\begin{tabular}{|l|l|l|}
\hline No & Bahasa Indonesia yang benar & $\begin{array}{l}\text { Bahasa Indonesia etnis } \\
\text { Rohingya }\end{array}$ \\
\hline 1 & Orang itu tidak bisa bahasa Aceh & Tidak tau bahasa Aceh orang \\
\hline 2 & Semua Kawan disini & ini rame-rame kawan \\
\hline 3 & Sudah makan & Makan sudah \\
\hline 4 & Kalau haus ini ada minuman & Ini haus-haus ada minum \\
\hline 5 & Sering-sering belajar & Banyak-banyak belajar \\
\hline 6 & Bahasa Indonesia & Indonesia bahasa \\
\hline 7 & Banyak-banyak bahasa & Rame-rame bahasa \\
\hline 8 & Belajar bahasa Indonesia & Bahasa Indonesia belajar \\
\hline
\end{tabular}

Tabel 4.4 Bahasa.

Menurut pengamatan peneliti, faktor terjadinya bahasa Indonesia seperti pada tabel di atas, yang pertama, etnis Rohingya belajar bahasa Indonesia hanya untuk bisa berbicara saja, artinya tidak belajar menulis dan membaca. Kedua, ketika sampai di Camp pengungsian etnis Rohingya terlebih dahulu belajar bahasa Inggris, sehingga pada saat mereka ingin mengetahui bahasa Indonesia, mereka belajar melalui bahasa Inggris. 
c. Hambatan-Hambatan Yang Mempengaruhi Proses Komunikasi Antarbudaya Pengungsi Etnis Rohingya dengan Masyarakat Aceh di Camp Bayeun Aceh Timur

Manusia adalah makhluk sosio-budaya yang memperoleh perilakunya lewat belajar. Apa yang manusia pelajari pada umumnya dipengaruhi oleh kekuatan-kekuatan sosial dan budaya. Dari semua aspek belajar manusia, komunikasi merupakan aspek yang sangat mendasar. Didalam proses komunikasi yang dijalani tentu akan ada hambatan-hambatan yang akan terjadi. Hambatan komunikasi atau yang juga dikenal sebagai communication barrier adalah segala sesuatu yang menjadi penghalang untuk terjadinya komunikasi yang efektif. Adapun hambatan-hambatan komunikasi antarbudaya yang terjadi antar pengungsi etnis Rohingya dengan masyarakat Aceh di Camp Bayeun Aceh Timur ialah:

1. Kemampuan etnis Rohingya yang hanya bisa berbahasa secara lisan dan tidak bisa melalui tulisan.Berdasarkan hasil wawancara yang peneliti lakukan diperoleh bahwa hambatan antropologis yang dialami antara etnis pengungsi Rohingya dengan masyarakat Aceh setempat ialah mengenai bahasa dan gaya hidup. Hambatan secara bahasa yang dialami ialah etnis Rohingya selama berada di Aceh meski sudah lebih dari setahun masih belum mampu menguasai bahasa Indonesia secara verbal sehingga untuk berkomunikasi dengan mereka hanya bisa dilakukan melalui percakapan saja atau secara lisan saja.

2. Perbedaan Gaya Hidup Antar Etnis Rohingya dan Masyarakat Aceh.Hambatan dari segi gaya hidup ialah seperti yang sudah dipaparkan oleh peneliti diatas yaitu perbedaan dalam hal penggunaan pakaian dimana orang etnis Rohingya tidak terbiasa menggunakan pakaian dalam pada mulanya dan harus membiasakan diri dan dalam hal kuliner ialah perbedaan rasa makanan, dimana etnis Rohingya menyukai makanan yang sangat pedas dan harus membiasakan diri untuk makan dengan masakan khas Aceh.

3. Penarikan diri dari komunikasi (kepribadian yang terlalu menutup diri dari lingkungan),komunikasi tidak mungkin terjadi bila salah satu pihak secara psikologis menarik diri dari pertemuan yang seharusnya terjadi. Hal inilah yang menjadi salah satu hambatan dalam komunikasi antarbudaya etnis Rohingya dan masyarakat Aceh. Tentu bukan tanpa alasan hal ini terjadi.

4. Etnis Rohingya Malas Untuk Berbicara .Menurut hemat peneliti hal ini terjadi karena etnis Rohingya terlalu fokus terhadap diri sendiri secara terus menerus sehingga sulit untuk memusatkan perhatian pada orang lain. Mereka berpikir tentang masalah yang 
mereka hadapi secara terus menerus dan terlalu menuntut orang atau masyarakat setempat agar secepatnya bisa menyelesaikan konflik yang mereka alami.

Solusi yang dapat ditawarkan agar tidak menjadi hambatan komunikasi antarbudaya antar etnis pengungsi Rohingya dengan masyarakat Aceh di Camp Bayeun Aceh Timur sebagai berikut:

Agar tidak terjadinya hambatan dalam berkomunikasi, maka etnis Rohingya berusaha untuk belajar seperti berbahasa melalui tulisan jangan hanya bisa berbahasa secara lisan. Karena tidak selamanya komunikasi itu terjadi dalam bentuk lisan, tetapi dalam bentuk tulisan atau simbol-simbol sangat penting untuk diketahui seperti dengan adanya informasiinformasi yang diumumkan pada papan pengumuman. Etnis Rohingya bisa belajar dengan seorang guru yang ahli dalam bidang bahasa Indonesia.

Begitu juga dengan perbedaan gaya hidup etnis Rohingya selama di Aceh. mereka tidak terbiasa dengan pakaian celana dalam dan juga makanan khas Aceh. oleh sebab itu masyarakat Aceh memperkenalkan hal tersebut kepada etnis Rohingya. Dengan demikian etnis Rohingya yang hidup di Aceh bisa menyusuaikan diri dengan masyarakat sekitarnya.

Hambatan berikutnya yaitu penarikan diri dari komunikasi atau kepribadian yang terlalu menutup diri dari lingkungan seperti sebagian dari mereka yakni etnis Rohingya menutup diri untuk berkomunikasi dengan masyarakat Aceh. Dan etnis Rohingya menganggap masyarakat Aceh yang hanya ingin berkomunikasi dengan mereka tidak menguntungkan bagi mereka. Maksutnya tidak akan menyelesaikan masalah yang mereka hadapi. Agar hal ini tidak menjadi hambatan dalam berkomunikasi, masyarakat Aceh memberi bantuan langsug kepada yang bersangkutan agar etnis Rohingya bisa merasakan kepedulian masyarakat Aceh terhadap mereka. hal tersebut dapat mengurangi sikap mereka yang tertutup sehingga tidak malas untuk berkomunikasi.

\section{H. Keseimpulan}

Berdasarkan hasil pengolahan data yang peneliti temukan dilapangan maka peneliti memperoleh kesimpulan sebagai berikut:

2. Komunikasi antarbudaya yang terjalin antara etnis Rohingya dengan masyarakat Aceh di Camp Bayeun Aceh Timur secara sosial memberikan keampuan bagi etnis Rohingya untuk bisa berkomunikasi dengan bahasa Indonesia yang pada akhirnya memberikanperubahan pada gaya hidup mereka seperti kebiasaan makan, berpakaian bahkan tata cara beribadah. Sedangkan bagi masyarakat Aceh kehadiran etnis 
Rohingya secara sosial dapat memperkuat nilai-nilai budaya yang sudah tertanam sebelumnya seperti cinta kasih, rasa empati bahkan keramah tamahan.

3. Hambatan-hambatan yang mempengaruhi terjadinya komunikasi antarbudaya pengungsi etnis Rohingya dengan masyarakay Aceh di Camp Bayeun Aceh timur ialah meliputi ketrbatasan etnis Rohingya dalam berbahassa yang hanya bisa secara lisan dan tidak bisa tulisan, penarikan diri dari komunikasi (kepribadian etnis Rohingya yang terlalu menutup diri dari lingkungan) dan etnis Rohingya malas berbicara atau berkomunikasi dengan masyarakat Aceh. 


\section{DAFTAR PUSTAKA}

Basrowi dan Sukidin, Metode Penelitian Kualitatif : Perspektif Mikro, Surabaya: Insan Cendikia, 2002

Berger, Peter L, Tafsir Sosial Atas Kenyataan, Jakarta: Lembaga Penelitian, Pendidikan, Dan Penerangan Ekonomi Dan Sosial, 1990

Bungin, Burhan, Metode Penelitian Kualitatif, Jakarta: Pt raja grafindo persada, 2008

Efendy, Onong Uchjana, Ilmu Komunikasi, Teori dan Praktek, Bandung: Remaja Rosdakarya, 1992

Hiadayat, Deddy Nu, Paradigma dan Perkembangan Penelitian Komunikasi dalam Jurnal Ikatan Sarjana Komunikasi Indonesia,VolIII. Jakarta: IKSI dan ROSDA, 1999

Mulyana, Deddy, Metodologi Penelitian Kualitatif, Paradigma Baru Ilmu Komunikasi dan Ilmu Sosial Lainnya, Bandung: Remaja Rosda Karya, 2001

Mulyana, Deddy, Ilmu Komunikasi Suatu Pengantar, Bandung: PT Remaja Rosda Karya, 2009

Mulyana, Deddy dan Rakhmat, Jalaluddin , Komunikasi Antarbudaya, Bandung: PT.Remaja Rosdakaraya, 2009

Muslich, Masnur, Bahasa Indonesia Pada Era Globalisasi Kedudukan, Fungsi, Pembinaan Dan Pengembang , Jakarta: Bumi Aksara, 2010

Notowidagdo, Rohiman, Ilmu Budaya Dasar, Jakarta: PT.Rajagrafindo Persada, 1996

Palupi, Bida, Mengenal Kajian Wacan Bahasa Indonesia, Jakarta: CV. Sahala Adidayatama, 2011

Saefullah, Ujang, Kapita Selekta Komunikasi Pendekatan Agama dan Budaya, Bandung: Simbiosa Rekatama Media, 2007

Samovar, Larry A., Richard, Porter E., dan McDaniel, Edwin R., Komunikasi Lintas Budaya, Jakarta: Salemba Humanika, 2010

Sugiyono, Metode Penelitian Kuantitatif, Kualitatif dan R\&B, Cet. 8, Bandung: Alfabeta, 2009

Sunarwinadi, Ilya, Ilmu Komunikasi Antar Budaya, Jakarta: Pusat Antar Universitas, 1993

Suprato, Metodologi Riset dan Aplikasi Dalam Pemasaran, Jakarta: Rineka Cipta, 1999

Soekanto, Soerjono, Sosiologi Suatu Pengantar, Jakarta: PT. Rajagrafindo Persada, 2007 
Usman, A. Rani, Etnis Cina Perantauan di Aceh, Jakarta: Yayasan Obor Indonesia, 2009

Widagdho, Djoko dkk, Ilmu Budaya Dasar, Jakarta: Bumi Aksara, 2010

Wirawan, I.B., Teori-Teori Sosial Dalam Tiga Paradigma, Fakta Sosial, Definisi Sosial \& Perilaku Sosial, Cet. 2, Jakarta: Kencana Prenada media Group, 2013 